\title{
Neuroscience, Sincerity, and the Law
}

\author{
JONATHAN KAHN* \\ 'The thought of man shall not be tried, for the devil himself \\ knoweth not the thought of man'. \\ -- Chief Justice Bryan, 1468
}

\section{Introduction}

In 1957 Oscar Smith and Derrick Bell opened their foundational article on discerning sincerity in claims of conscientious objection to military service with the above quoted epigraph from a 1919 law review article by Harlan Fiske Stone. ${ }^{1}$ Evaluating the sincerity of a statement in legal contexts is similar to but often quite distinct from evaluating the truth or falsity of a statement. The latter frequently refers to knowledge regarding matters of objective fact - 'did you steal the car?' 'where were you on that night?' etc. - that generally involve events in the past, that is events that occurred prior to the time a witness is presenting testimony about them in a legal forum. Even when a state of mind is directly at issue, as for example in determining malice, its relevance relates to its existence at some time in the past when an act occurred. Where sincerity is legally relevant, particularly in cases such as conscientious objection, it is being evaluated in real time - that is, the witness generally is not being asked to verify past objective events or attitudes but to testify as to his or her current state of mind. This is where Justice Bryan's concern comes in, for

\footnotetext{
Jonathan Kahn is Professor of Law at Mitchell | Hamline School of Law. He holds a Ph.D. in U.S. History from Cornell University and a J.D. from the Boalt Hall School of Law, University of California, Berkeley. His current research focuses on the intersections of law and biotechnology, with particular attention to how regulatory mandates intersect with scientific, clinical and commercial practice in producing legal understandings of race and racism in American society. $\mathrm{He}$ is the author of Race in a Bottle: The Story of BiDil and Racialized Medicine in a PostGenomic Age (Columbia University Press 2012). Much of his work can be viewed at http://ssrn. com/author $=180388$.

1 Smith \& Bell, The Conscientious-Objector Program - A Search for Sincerity, 19 U. Pitt. L. Rev. (1958) pp. 695 ff., at 695.
}

This is an Open-access article distributed under the terms of the Creative Commons Attribution 3.0 Unported License (http://creativecommons.org/licenses/ by/3.0/, permitting all use, distribution, and reproduction in any medium, provided the original work is properly cited. 
ultimately what is being evaluated is not the relation between the witness' statement and some objectively verifiable fact that occurred in the past, but the relation between the statement and the witness' own current state of mind. For this reason, courts have often been loath to tread into this territory.

This article will focus on the United States to consider how recent developments in neuroscience, specifically in the ability of researchers to measure directly certain types of brain activity through technologies such as functional Magnetic Resonance Imaging (fMRI), might be used so as to render states of mind, such as sincerity, measurable as 'objective facts' on a par with other observable phenomena for the purposes of resolving specific legal cases. As leading scholars of neuro law, Francis Shen and Owen Jones have noted, 'In all of human and legal history prior to just a few years ago, we have had to infer what was going on in a person's brain from a triangulation of circumstances, testimony, and projections of introspections.' ${ }^{2}$ They argue that new developments in neuroscience have the potential to change that - to take us where 'the devil himself' cannot go.

The primary focus will be on sincerity itself, particularly in relation to religious beliefs that are claimed as a basis for exemption for compliance with an existing statutory regime of general applicability. Part one will examine how the issue of sincerity has manifested itself in disputes concerning conscientious objections to participating in the military draft. This area provides a well-developed area of legal analysis of issues relating to assessing religious sincerity in existing case law. Part two will review the science of fMRI and consider issues raised by the use of fMRI scans as evidence in legal cases. Part three will address these issues specifically as they might bear on considerations raised in the conscientious objector cases discussed in part one. It will consider the challenges of applying fMRI technology to these sorts of cases. Part four will then consider the recent case of Burwell v. Hobby Lobby Stores, Inc., ${ }^{3}$ where the U.S. Supreme Court upheld a closed corporation's claim under the Religious Freedom Restoration Act to be exempt from complying with a provision of the Affordable Care Act concerning the provision of medical insurance to employees that covered certain forms of contraception because it substantially burdened the religious beliefs of its owners - effectively attributing their beliefs to the corporation. The Court explicitly did not consider the sincerity of claims in this case, but this paper will explore how the adoption of fMRI technology could potentially change this approach.

Before proceeding, it should be noted that I am actually extremely skeptical of the wisdom, practicality, and legal viability of applying fMRI testing to evaluate a subject's claims of sincerity. As I elaborate further below, there are many technical problems with developing, producing and interpreting fMRI data. I believe the basic problem with fMRI

2 Shen \& Jones, Brain Scans as Evidence: Truths, Proofs, Lies, and Lessons, 62 Mercer L. Rev. (2011) pp. 861 ff., at 862.

134 S.Ct. 2751 (2014). 
and related technologies is not the level of technical accuracy of the images produced. If that were all, then simple advances in technique might conceivably overcome such technical objections. More fundamentally, I believe the meaning of such images is not transparent, particularly as relates to legally relevant concepts of truth, sincerity, or accountability. Where simply organic processes are involved, such as situations where a physical injury to the brain has directly impaired certain cognitive functions, fMRI may indeed have a role to play. But with more complex situations such as truth-telling and sincerity - which must be understood as complex combinations of cognitive functions, social processes, historical contexts and interpretive regimes, the utility of fMRI is much more limited, if for no other reason than the issues at stake are not purely physical or technical in nature, but also normative and cultural. I, however, do not make the law and the simple fact of the matter is that the use of such technology in legal contexts is growing both in and out of court. ${ }^{4}$ It has recently come of age in the legal academy as the first casebook on Law and Neuroscience made its appearance in $2014 .{ }^{5}$ It therefore behooves critics such as myself, not only to challenge existing arguments for proposed uses but also to evaluate possible new areas of application, such as sincerity determination.

\section{Part One: Conscientious Objection to the Military Draft}

The history of statutory solicitude for conscientious objectors in the United States goes back at least to the Civil War era Draft Law of 1864 which allowed members of pacifist religious denominations to declare their conscientious opposition to military service. ${ }^{6}$ The Selective Service Act of 1917 similarly contained a provision for conscientious objectors that was limited to members of well-recognized religious sects with clearly stated objections to participation in war. ${ }^{7}$ During World War II, the Selective Service Act extended conscientious objector status to all those who 'by reason of religious training and belief', were conscientiously opposed to participation in war in any form. ${ }^{8}$ Significantly, the earlier laws effectively used membership in a pacifist sect or denomination as a proxy for a sincere religiously-based objection to military service. Such membership was objectively verifiable and the tenets of the relevant religion were similarly ascertainable. By eliminating the express requirement of belonging to a recognized pacifist denomination or sect, the 1940 law brought the sincerity of the individual's belief to the fore as a basis for determining claims for conscientious objector status. Writing in 1957 concerning the then

4 See, for example, Volume 50, issue 2 (2014) of the Court Review, the journal of the American Judges Association, which is entirely devoted to examining current and future uses of neuroscience in the law.

5 Jones, Schall \& Shen, Law and Neuroscience (Wolters Kluwer Law \& Business 2014).

6 Smith \& Bell, supra note 1, at 696.

$7 \quad$ Ibid.

$8 \quad$ Ibid. at 697. 
current law which contained a similar sort of exemption, Smith and Bell therefore noted that 'the adjudication of a man's conscience is a delicate and difficult task. Nevertheless, determination of the subjective sincerity of each claim is vital to the success of any Conscientious-Objector program. ${ }^{9}$ They observed that there was no empirical method for directly testing sincerity so that boards reviewing claims could 'test the registrant's sincerity only by hearing his indicated beliefs, comparing these with his past activities and statements as reported by those with whom he has associated. Objective facts, though helpful, may be misleading since many registrants who are making their claims in good faith have backgrounds which belie any religious feeling. ${ }^{10}$ To drive home the point, they quoted a passage from United States $v$. Simmons, where the Seventh Circuit Court of Appeals asserted that

Probing a man's conscience is, at best, a speculative venture. No one, not even his closest friends and associates, can testify to a certainty as to what he believes and feels. These, at most, can only express their opinions as to his sincerity. The best evidence on this question may well be, not the man's statements or those of other witnesses, but his credibility and demeanor in a personal appearance before the fact-finding agency. ${ }^{11}$

In short, the best one could hope to do in evaluating the sincerity of a claim was to look at such subjective indicators as credibility and demeanor.

The parameters of contemporary doctrine on conscientious objection were laid out most influentially in the Vietnam era cases of United States v. Seeger ${ }^{12}$ and Welsh v. United States. ${ }^{13}$ Seeger involved challenges to section 6(j) of the Universal Military Training and Service Act, 'which exempts from combatant training and service in the armed forces of the United States those persons who by reason of their religious training and belief are conscientiously opposed to participation in war in any form. ${ }^{14}$ Specifically, the parties challenged the constitutionality of the section which defines the term 'religious training and belief', as used in the Act, as 'an individual's belief in a relation to a Supreme Being involving duties superior to those arising from any human relation, but (not including) essentially political, sociological, or philosophical views or a merely personal moral code, ${ }^{15}$ on the grounds 1) that it violated the First Amendment Establishment and Free Exercise clauses because it did not exempt nonreligious conscientious objectors; and 2)

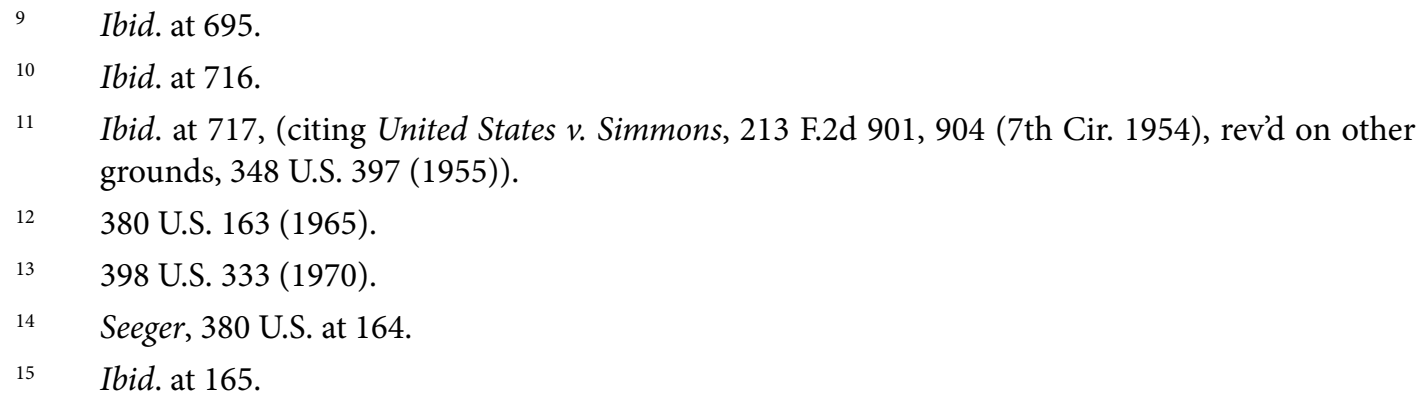


that it discriminated between different forms of religious expression in violation of the Due Process Clause of the Fifth Amendment. ${ }^{16}$

In deciding the case the Court concluded that, 'the test of belief 'in a relation to a Supreme Being' is whether a given belief that is sincere and meaningful occupies a place in the life of its possessor parallel to that filled by the orthodox belief in God of one who clearly qualifies for the exemption. Where such beliefs have parallel positions in the lives of their respective holders we cannot say that one is 'in a relation to a Supreme Being' and the other is not. ${ }^{17}$ The Court is careful to note however, that the 'validity of what he believes' itself is not to be questioned, rather the task of local boards and courts is simply 'to decide whether the beliefs professed by a registrant are sincerely held and whether they are, in his own scheme of things, religious.' ${ }^{18}$ The Court emphasized, however, that 'while the 'truth' of a belief is not open to question, there remains the significant question whether it is 'truly held'. This is the threshold question of sincerity which must be resolved in every case. ${ }^{19}$ Sincerity was the touchstone, yet in Seeger's particular case, the Court noted that the sincerity with which he held his beliefs was 'unquestioned' - the only real issue was whether those beliefs held the same place in his life as an orthodox belief in God holds in the life of one clearly qualified for exemption. ${ }^{20}$ The Court concluded that had the lower Court applied this test, it would have clearly answered in the affirmative. ${ }^{21}$

Where Seeger extended conscientious objector status to those holding beliefs that occupied a place in their life similar to a belief in God, in Welsh, the Court went further to accord such status to 'deeply and sincerely [held] beliefs that are purely ethical or moral. i.e. non-religious. ${ }^{22}$ While sincerity was central to both opinions, the Court did not directly express concerns over the ability of finders of fact to assess such sincerity. It impliedly accepted the resort to traditional assessments of credibility and demeanor that Smith and Bell had earlier noted characterized previous approaches to evaluating individual claims of sincerity. Similarly, the case of Burwell v. Hobby Lobby involved the issue of whether the Affordable Care Act's requiring of a closely held corporation to provide health insurance coverage that included contraceptives violated the sincerely held religious beliefs of the owners. As in Welsh and Seeger the Court declined to examine the sincerity of the beliefs at issue - yet perhaps in the future, developments in neuroscience might lead the Court to decide otherwise.

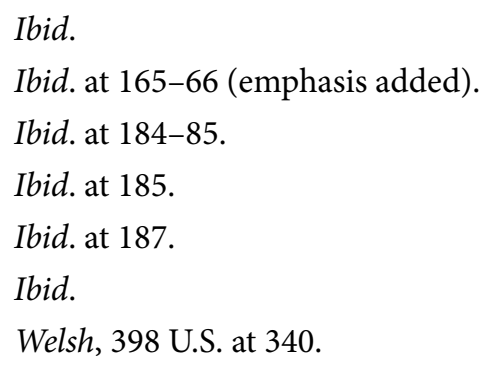




\section{Part Two: Neuroscience and Access to States of Mind}

Justice Bryan's protestations to the contrary notwithstanding, the law, of course, is often deeply concerned with 'the thought of a man' (or woman) as scienter plays a central role in determining a myriad forms of legal responsibility in both civil and criminal law contexts. It is largely understood, however, that legally relevant states of mind are generally derived inferentially from context, demeanor, credibility and circumstance. Triers of fact do not have direct access to a person's subjective thoughts in the same way that they may have access to material forms of evidence. This, however, has not stopped people from seeking such access.

In medieval times those suspected of heresy or witchcraft might be subject to a variety of physical ordeals by fire or water to test the sincerity of their avowals. ${ }^{23}$ Over the past century more modern technologies have supplanted appeals to the supernatural to evaluate the credibility of witnesses in legal contexts. Most well-known among these is the polygraph. Developed in the early $20^{\text {th }}$ century, the polygraph measured various outputs of the sympathetic nervous system, such as blood pressure, heart rate, respiration and perspiration, to try to detect whether a given subject was telling a lie. Scientific skepticism about the reliability and validity of polygraph testing (as well as its susceptibility to countermeasures) has generally curtailed its widespread use in legal fora. Indeed, the use of polygraphs is legally forbidden in non-governmental pre-employment screening and only rarely admitted in court for limited purposes. ${ }^{24}$ Nonetheless, particularly in a post9/11 world, many U.S. security agencies continue to use polygraphs to screen current and prospective employees. Yet a report by the National Academies of Science found polygraph testing too flawed for security screening, ${ }^{25}$ and one critical article by leading legal experts cautions that 'in national security applications, overconfidence in polygraph screening can create a false sense of security. ${ }^{26}$

The latest entry into the field of technologically mediated methods for lie detection is functional Magnetic Resonance Imaging (fMRI). To take a standard MRI a subject typically lies on a table, places their head in an apparatus that helps keep it still, and then is slid back so that their head enters a donut-shaped magnetic core. The MRI uses a pulse of radio waves to temporarily knock protons out of alignment in a targeted area and then

23 See, e.g., Bartlett, Trial by Fire and Water: The Medieval Judicial Ordeal (Clarendon Press 1986).

24 Farahet et al., Functional MRI-based lie detection: scientific and societal challenges, 15 Nature Reviews Neuroscience (2014) pp. $123 \mathrm{ff}$., at 124.

25 National Academy of Science, Polygraph Testing Too Flawed for Security Screening (Oct. 8, 2002), available at http://www8.nationalacademies.org/onpinews/newsitem.aspx?recordid=10420 [all websites in this article are last checked 16/12/2015].

26 Faigman et al., The Limits of the Polygraph, 20 Issues in Science and Technology (2003) pp. $40 \mathrm{ff}$., available at http://issues.org/20-1/faigman/ 
uses the magnet to measure the radio waves they emit as they relax back into alignment. Computers then take this data and process it to create an image of the subject's brain. An fMRI is 'functional' in the sense that it is able to measure the flow of blood to particular parts of the brain during specified tasks undertaken while the subject is in the MRI machine. It is able to do this because measureable levels of iron in the blood vary depending on its degree of oxygenation. Since blood oxygenation varies according to the levels of neural activity these differences can be used to detect brain activity. ${ }^{27}$ The device gathers information about the subject's Blood Oxygen Level Dependent ('BOLD') response. By comparing the subject's BOLD response signals with a control state, small changes in signal intensity are detectable and can provide information about brain activity. ${ }^{28}$ I suppose if this technology were available in medieval times they might have referred to it as 'ordeal by radio waves'.

In recent years there have been a number of technical critiques of fMRI methodologies and interpretations. Perhaps foremost among these involves the 'W.E.I.R.D'. problem in psychology and neuroscience research. 'W.E.I.R.D'. stands for 'Western, Educated, Industrialized, Rich, and Democratic', which aptly characterizes the demographic characteristics of most subjects of neuroscience research..$^{29}$ One review of a comparative database across the behavioral sciences suggested 'both that there is substantial variability in experimental results across populations and that WEIRD subjects are particularly unusual compared with the rest of the species - frequent outliers. ${ }^{30}$ The basic concern is that studies on W.E.I.R.D. subjects, particularly university undergraduates who often provide a readily accessible pool of research subjects for psychology professors, form the empirical foundation for claims being made more broadly about the basic characteristics of human nature and the functioning of the brain. ${ }^{31}$ Other concerns with fMRI studies include a recent analysis showing that 'the average statistical power of studies in the neurosciences in very low' leading to 'overestimates of effect size and low reproducibility of

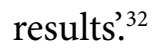

27 American Psychological Association: Science Directorate Functional Magnetic Resonance Imaging: A New Research Tool (2007), available at http://www.apa.org/research/tools/fmriadult.pdf

Center for Functional MRI, What is fMRI?, UC San Diego School of Medicine, available at http://fmri.ucsd.edu/Research/whatisfmri.html

28 Brown \& Murphy, Through a Scanner Darkly: Functional Neuroimaging as Evidence of a Criminal Defendant's Past Mental States, 62 Stan. L. Rev. (2010) pp. 1119 ff., at 1139-40.

29 Henrich, Heine \& Norenzayan, The weirdest people in the world?, in Behavioral and Brain Sciences (2010) pp. $33 \mathrm{ff}$., at 61-135.

$30 \quad$ Ibid.

31 Ibid. See also, Burton, A Skeptics Guide to the Mind (St. Martin’s Press 2013), pp. 105-107.

32 Button et al., Power failure: why small sample size undermines the reliability of neuroscience, 14 Nature Rev. Neurosci (2013), pp. 1-12, at 1. 
Perhaps most infamous is a controversy that recently arose around what one scholar terms 'the salmon of doubt. ${ }^{33}$ The salmon at issue was a dead one, purchased at a fish market by neuroscientist Craig Bennett who then took it to his lab at Dartmouth, placed it in an fMRI and showed it a series of photographs depicting human individuals in social situations with a specified emotional valence, ${ }^{34}$ just as with humans in many of the race and brain activation studies. In the fMRI scan, it looked like the dead salmon was actually thinking about the pictures it had been shown. 'By complete, random chance, we found some voxels that were significant that just happened to be in the fish's brain', Bennett told Wired magazine. 'And if I were a ridiculous researcher, I'd say, "A dead salmon perceiving humans can tell their emotional state". ${ }^{35}$ The point is not that fMRI is illegitimate or produces ridiculous results. Rather, it highlights the fact that these results are not direct and transparent representations of the brain functioning but rather are highly complex, technologically mediated statistical constructions of results that have many steps involving human interventions to set parameters and construct results in a manner that can actually be highly subjective. ${ }^{36}$ As Science Studies scholar Joe Dumit argued in his study of positron emission tomography (PET) scans, these images are not simply captured, rather they are critically produced in four stages: first, designing the experiment, which 'involves choosing participants for the study and designing their state and behavior in the scanner'; second, 'measuring brain activity', where 'a scanner must properly collect the data, and then a computer must algorithmically reconstruct the data into a three dimensional map of activity, based on assumptions about the scanner and brain activity'; third, 'making data comparable', which entails transforming and normalizing scans so that an individual's 'brain locations can be correlated with those of others'; and, fourth, 'making comparable data presentable', this typically involves two steps, 'first, colors are used to substitute form the numbers in the dataset, and second, specific colored brainsets are selected, to be produced and published. Coloring involves transforming numeric variation into a contour map, highlighting some differences at the expense of others. ${ }^{37}$

One particularly controversial paper exploring some of these implications for fMRI studies of such subjective choices by Vul et al. was initially titled 'Voodoo Correlations'

33 Margulies, The Salmon of Doubt: Six Months of Methodological Controversy within Social neuroscience, in Critical Neuroscience: A Handbook of the Social and Cultural Contexts of Neuroscience, eds Choudhury \& Slaby (Wiley-Blackwell 2012), pp. 273-285.

34 Bennett et al., Neural correlates of interspecies perspective taking in the post-mortem Atlantic Salmon: An argument for multiple comparisons correction. Available at: http://prefrontal.org/ files/posters/Bennett-Salmon-2009.pdf

35 Madrigal, Scanning Dead Salmon in fMRI Machine Highlights Risk of Red Herrings, in Wired 09.18.09, available at http://www.wired.com/2009/09/fmrisalmon/

$36 \quad$ Ibid.

37 Dumit, Critically Producing Brain Images of Mind, in Critical Neuroscience: A Handbook of the Social and Cultural Contexts of Neuroscience, eds Choudhury \& Slaby (Wiley-Blackwell 2012)pp. 195-225, at 198-199. 
and later renamed, 'Puzzlingly High Correlations in fMRI Studies of Emotion, Personality, and Social Cognition'.38 The paper involves the widespread finding of 'non-independence error' in many social neuroscience papers which attempt to correlate activity in certain parts of the brain (measured using fMRI) against behavioral or self-report measures of 'social' traits - essentially, personality. Non-independence error involves not the measurement of data per se, but the subjective selection of data within larger sets where researchers tend to pick out results with higher values. ${ }^{39}$ The overall average of such numbers will tend to show significant results where they might not really exist. ${ }^{40}$

Despite such critiques, fMRI scans and similar tools of neuroscience are being be used to detect all sorts of potentially legally relevant things about the brain. In some cases they can be used to diagnose organic impairments of functional activity. Thus for example, Owen Jones and Christopher Sundby note that neuroimaging evidence has been proffered in civil cases to make claims regarding mental competence or indicate injuries such as concussions or to establish the extent of particular injuries to the brain. ${ }^{41}$ It might also be used to establish the presence or degree of pain being experienced by, for example, a claimant to unemployment compensation or SSI disability. ${ }^{42}$ Perhaps most prominent is the 2005 case of Roper v. Simmons ${ }^{43}$ where the U.S. Supreme Court held that the 8th and 14th Amendments forbade the imposition of the death penalty on youths who committed their crimes before the age of 18 . Several organizations submitted amicus briefs presenting evidence from neuroscience arguing that the brains of adolescents were not fully developed in critical regions related to impulse control and so adolescents should not be held fully accountable to the same degree as adults in capital cases. The Supreme Court referenced this evidence but it does not seem to have played a central role in the Court's determination. ${ }^{44}$

Much more contentious is the question of whether or how to use fMRI evidence to evaluate the credibility of statements by a witness. The Supreme Court notably articulated a 'gatekeeping' role for the trial court judge in considering the admissibility of scientific evidence in the 1993 case of Daubert v. Merrell Dow Pharmaceuticals, Inc. ${ }^{45}$ Central to

38 Vul et al., Puzzlingly High Correlations in fMRI Studies of Emotion, Personality, and Social Cognition, in 4 Perspectives on Psychological Science (2009), pp. 274-290.

39 Ibid.

40 Ibid. For a general discussion of the controversy elicited by the paper, see Margulies, supra note 33.

$41 \quad$ Jones \& Sundby, Neuroscience in the Law, 11 The SciTech Lawyer (2015), pp. 4 ff., at 6.

42 Pustilnik, Pain as Fact and Heuristic: How Pain Neuroimaging Illuminates Moral Dimensions of Law, in 97 Cornell L. Rev. (2012) pp. 801 ff.; Reardon, Neuroscience in Court: The Painful Truth, 518 Nature (2015), pp. $474 \mathrm{ff}$.

$43 \quad 543$ U.S. 551 (2005).

$44 \quad$ Roper, 543 U.S. at 569.

$45 \quad 509$ U.S. 579 (1993). 
the holding in Daubert was the Court's articulation of a requirement that the trial judge ensure that 'an expert's testimony both rests on a reliable foundation and is relevant to the task at hand. ${ }^{46}$ Federal Rule of Evidence ('FRE') 401 further states that relevant evidence means evidence that has 'any tendency to make a fact more or less probable than it would be without the evidence' and 'the fact is of consequence in determining the action. ${ }^{47}$

The recent case of United States $v$. Semrau indicates that, at least for now, the use of fMRI scans as lie detectors in federal criminal cases is not yet ready for prime time. ${ }^{48}$ In appealing his conviction for healthcare fraud, Dr. Lorne Semrau argued that results from an fMRI lie detection test should have been admitted to prove the veracity of his assertions that he did not knowingly submit false claims. ${ }^{49}$ In preparation for trial, Semrau had contracted with Cephos, one of two corporations currently offering commercial fMRI lie detection tests, or what is also called 'Truth Verification Technology'. ${ }^{50}$ Cephos administered tests purporting to show the truthfulness of Semrau's claims regarding his lack of intent to defraud. Before trial, United States Magistrate Judge Tu Pham conducted a hearing on the admissibility of brain-based lie detection evidence. Judge Tam applied four factors set forth in Daubert to assess the reliability of the neuroscience evidence and testimony:

(1) whether the theory or technique can be tested and has been tested; (2) whether the theory or technique has been subjected to peer review and publication; (3) the known or potential rate of error of the method used and the existence and maintenance of standards controlling the technique's operation; and (4) whether the theory or method has been generally accepted by the scientific community. ${ }^{51}$

Judge Pham found the evidence failed to satisfy the third and fourth factors. Cognitive scientists Farah et al. note that his report focused in particular on 'the lack of general acceptance for the method within the scientific community; the substantial differences between laboratory research designs and the real-world use of fMRI-based lie detection in this case; the lack of 'real-life' error rates; and the lack of suitably controlling standards for the use of the method. ${ }^{52}$ Judge Pham therefore concluded that 'at least at this early stage in its development, fMRI-based lie detection does not satisfy the requirements of

\footnotetext{
$46 \quad$ Ibid. at 597.

$47 \quad$ Fed. R. Evid. 401.

$48 \quad 693$ F.3d 510 (2012).

49 Semrau, 693 F.3d at 513.

50 This term is from No Lie MRI, the other company offering commercial fMRI lie detection services. No Lie MRI, http://www.noliemri.com/.

${ }_{51}$ United States v. Semrau, No. 07-10074 M1/P, 2010 WL 6845092, at *9 (W.D. Tenn. June 1, 2010).

$52 \quad$ Farah et al., supra note 24, at 128.
} 
Rule 702.53 On appeal, the Circuit Court affirmed this decision. ${ }^{54}$ At the state level, a Maryland trial court applying the Frye standard of general acceptance similarly rejected a test conducted by Cephos's primary competitor, No-Lie MRI on the basis that there was 'no quantitative analysis of [the] procedure. ${ }^{55}$

In their excellent analysis of the Magistrate's order, Francis Shen and Owen Jones elaborate on some of the issues identified by Farah et al. concerning existing technical aspects of why admitting brain scans as evidence remains highly problematic given the current state of the technology. These include problems such as using baseline date that is derived from experiments based on group averages to derive conclusions about a specific individual's truthfulness, or similarly, how it is to apply measurements derived from laboratory settings to real-world contexts. ${ }^{56}$ These technical questions, however, might conceivably be addressed through further refinements in the technology. Thus, for example, despite their skepticism concerning the present state of fMRI lie detection, Farah et al. urge that 'publicly funded research should be undertaken to explore the potential of fMRI-based lie detection'; ${ }^{57}$ or as one neuroscience blog commenting on the Farah et al. article put it: it [fMRI lie detection] is not something we are likely to see gain widespread acceptance anytime soon. But that does not mean it is not a future possibility.58

Yet, even if such technical problems were addressed, one addition problem would remain: the fact that in cases such as Semrau's the state of mind legally at issue has to be established as existing at a time in the past when the relevant action (such as fraud) occurred. No measurement of a person's state of mind at the time of trial, no matter how accurate, can be sure of capturing a past state of mind. ${ }^{59}$ This problem, however, is not present in the case of evaluating the sincerity of conscientious objectors whose state of mind is legally relevant at the time of the hearing where the evidence would be proffered. It is to this situation that we now turn.

53 Shen \& Jones, supra note 2, at 871, quoting Semrau, 2010 WL 6845092, at *10.

$54 \quad$ Semrau, 693 F.3d at 513.

55 Meixner Jr., Applications of Neuroscience in Criminal Law: Legal and Methodological Issues, in 15 Current Neurology Neuroscience Reports (2015), pp. 513 ff., at 515, citing Smith v. State, 32 A.3d 59 (Md. 2011).

$56 \quad$ Shen \& Jones, supra note 2, at 882; see also Meixner, supra note 55, at 514.

$57 \quad$ Farah et al., supra note 24, at 130.

58 Detecting lies with fMRI, Neuroscientifically Challenged (Dec. 12, 2014), available at: http://www.neuroscientificallychallenged.com/blog/detecting-lies-with-fmri

$59 \quad$ Shen \& Jones, supra note 2 , at 862. 


\section{Part Three: Neuroscience and Sincere Conscientious Objection}

Following the Supreme Court's decision in Welsh, one commentator noted, '[t]here are few tasks more difficult than judging the sincerity of another man's belief.' ${ }^{\prime}{ }^{0}$ He went on to quote a 4th Circuit opinion noting that, 'human experience has devised no precise gauge for appraising a subjective belief lodged in the mind and heart of the person.61 Nonetheless, he recognized that making a factual determination of the intrinsic sincerity of each claim of conscientious objector status is vital. Yet, he concluded that ' $\mathrm{t}$ ] he present test of sincerity lacks the essential specialized techniques demanded by the peculiar nature of the claim. ${ }^{62}$ As neuroscience develops, it merits considering whether such specialized techniques may soon be at hand and how they might change approaches to assessing sincerity in contexts such as claims of conscientious objection.

While there have been many studies of using fMRI to detect lies, legal scholars and neuroscientists alike have paid comparatively little attention to using it to evaluate sincerity. There are some significant differences between in using fMRI scans as lie detectors in criminal settings and using them to assess the sincerity of religious claims. First, as noted above, evaluations of sincerity can take place in real time; that is the state of mind being evaluated at the time of the test is the state of mind directly at issue in law, whereas lie detection evidence typically involves asking questions about the subject's participation in past events. Second, even where state of mind might be at issue in a criminal case, as in assessing malice and intent, it matters primarily in relation to a distinct legally proscribed act such a battery or fraud. In a claim of conscientious objection, state of mind stands alone as the primary issue to be addressed independent of its relation to any other action. Third, proffering neuroscientific evidence of sincerity in a case of conscientious objection raises fewer Constitutional concerns regarding invasion of privacy, self-incrimination, or right to jury trial. In a criminal law context, if future fMRI testing were regarded by courts as no more invasive that a breathalyzer or blood test, then conceivably, legal authorities might seek warrants to obtain fMRI scans in the course of an investigation. If the results of such tests were regarded as material rather than testimonial evidence then they might not be protected by the $5^{\text {th }}$ Amendment privilege against self-incrimination. Finally, the force of such fMRI evidence might undermine the constitutionally guaranteed right to trial by jury by displacing its role as the primary evaluator of witness credibility. ${ }^{63}$ Because the burden of establishing sincerity is on the person asserting conscientious ob-

60 Mott, Successful Evaluation of Sincerity After Welsh, 11 Santa Clara Lawyer (1971), pp. 381 ff., at 385 .

$61 \quad$ Ibid., quoting Blalock v. United States, 247 F.2d 615, 618 ( $4^{\text {th }}$ Cir. 1957).

62 Mott, supra note 60, at 385.

63 Fox, Brain Imaging and the Bill of Rights: Memory Detection Technologies and American Criminal Justice, in 8 The American Journal of Bioethics (2008), pp. 34 ff., at 35-36. 
jector status, ${ }^{64}$ this person would have the option to proffer fMRI evidence and control the terms of its production and presentation. Certainly in a case such as Semrau where the defendant was proffering the evidence, there is less direct coercion or more control over the testing. Yet, I would argue that the level of implicit coercion in a situation where a person is already facing criminal charges is inherently more direct than a case where no violation has yet been found and the subject is merely trying to establish a basis for exemption from a statute.

What then does the current state of neuroscience have to say about assessing the sincerity of a subject particularly in relation to religious matters? Insincerity, of course, shares many characteristics with lying. They may often overlap in particular situations, but they really are distinct matters, particularly if one considers that lie detection in legal settings most often involves statements concerning objectively verifiable facts - e.g. did you rob the store? - whereas sincerity deals more with the intensity and clarity of subjectively held beliefs or values - e.g. do you believe in God? There has been much research into looking for what has been characterized as the 'neural correlates of religious belief', 65 but little on using fMRI to evaluate the sincerity of such belief. One recent study used functional neuroimaging to compare modes of cognition associated with belief as a general mode of cognition to specifically religious belief. ${ }^{66}$ The study used fMRI to measure signal changes in the brains of thirty subjects, 'fifteen committed Christians and fifteen nonbelievers' they evaluated the truth and falsity of religious and nonreligious propositions, such as 'The Biblical God really exists' as opposed to 'Santa Claus really exists. ${ }^{67}$ The findings suggested that different regions of the brain were activated in response to engaging religious beliefs as opposed to beliefs about non-religious subjects. While not directly bearing on the issue of detecting the sincerity of religious belief, the study does assert that 'these opposing states of cognition can be discriminated by functional neuroimaging' in a manner that might lead to the ability to use fMRI as a manner of 'belief detection' that might serve to complement or extend its potential use as a 'lie detector.' ${ }^{68}$

Returning then to the Smith and Bell article of 1957, let us consider how some future use of fMRI might address the core concern expressed in the quotation they drew from the $7^{\text {th }}$ Circuit Court of Appeals:

64 Mott, supra note 60, at 385.

${ }_{65}$ See, e.g., Harris et al., The Neural Correlates of Religious and Nonreligious Belief, PLoS ONE e0007272 (2009); Kapogiannisa et al., Cognitive and neural foundations of religious belief, 106 PNAS (2009), pp. $4876 \mathrm{ff}$. There is even an organization called the International Association for the Cognitive Science of Religion devoted to promoting research in the area: http://www.iacsr.com/iacsr/Home.html

${ }_{66}$ See, e.g., Harris op.cit.; Kapogiannisa, op.cit.

67 Harris op.cit., at 7.

$68 \quad$ Ibid. at 6. 
Probing a man's conscience is, at best, a speculative venture. No one, not even his closest friends and associates, can testify to a certainty as to what he believes and feels. These, at most, can only express their opinions as to his sincerity. The best evidence on this question may well be, not the man's statements or those of other witnesses, but his credibility and demeanor in a personal appearance before the fact-finding agency. ${ }^{69}$

If the technical problems discussed in the previous section could be adequately addressed, then fMRI could present a real opportunity to remove assessments of sincerity from the realm of speculation, rendering them much more akin to evaluations of material fact. Such evidence might not wholly supplant a fact-finder's evaluation of a subject's credibility and demeanor but could surely complement it.

Consider that historically, local draft boards have often been highly skeptical of claims of conscientious objection, particularly by people who did not belong to recognized pacifist denominations. For example, writing of the experience during the Viet Nam era, one commentator has noted that 'lacking expertise and with only a minimal basis for judging sincerity, many conscientious but cautious boards are reluctant to take the initiative in deciding in favor of CO's.70 The burden of establishing sincerity is on the claimant. Given a typical claimant's youth, inexperience and frequent lack of competent legal counsel this burden has historically been very hard to meet. ${ }^{71}$ In such a situation, a simple fMRI scan (assuming should such a procedure could be rendered simple and routine, like many other medical procedures) both could help the sincere claimant significantly. Moreover, the context of a civil hearing where the subject is requesting an exemption from a statute would serve to mitigate the sorts of constitutional concerns raised by the use of fMRI in criminal trial contexts where the subject is before a tribunal involuntarily and is seeking to establish innocence (or at least reasonable doubt) rather than merely sincerity. Finally, the existence of fMRI sincerity tests might deter those less confident of their sincerity from presenting such claims, thereby serving interests of administrative efficiency. note that in determining sincerity courts have also looked at such evidence as the time when a claim is filed, factual misrepresentations made in completing the exemption forms and prior military experience, Ibid. at 717 .

70 Mott, supra note 60, at 386.

$71 \quad$ Ibid. at $385-6$. 


\section{Part Four: Neuroscience and Corporate Sincerity - The Case of Burwell v. Hobby Lobby ${ }^{72}$}

The Hobby Lobby case involved two closely held corporations seeking an exemption under the Religious Freedom Restoration Act (RFRA) from providing certain contraceptive service coverage in their employee insurance programs pursuant to a mandate of the Affordable Care Act (ACA). RFRA prohibits the 'Government [from] substantially burden[ing] a person's exercise of religion even if the burden results from a rule of general applicability' unless the Government 'demonstrates that application of the burden to the person-(1) is in furtherance of a compelling governmental interest; and (2) is the least restrictive means of furthering that compelling governmental interest. ${ }^{73}$ The ACA already included exemptions for religious employers but this case involved for-profit corporate employers. In Hobby Lobby, the owners of the closely held corporations professed sincere Christian beliefs that life begins at conception and that it would violate their religion to facilitate access to contraceptive drugs or devices that operate after that point. They sued, arguing that the ACA mandate that they provide insurance covering such drugs or devices substantially burdened their free exercise of religion. The Court found for the plaintiffs and held that as applied to closely held corporations, the HHS regulations imposing the contraceptive mandate violated RFRA. ${ }^{74}$

At the outset of his opinion for the court, Justice Alito frames the issues as one of whether RFRA 'permits the United States Department of Health and Human Services (HHS) to demand that three closely held corporations provide health-insurance coverage for methods of contraception that violate the sincerely held religious beliefs of the companies' owners. ${ }^{75}$ Even though a corporation's rights are at issue, it is the sincerity of the individual owners' beliefs that was central to framing the issues before the Court. Yet, ultimately, the Court sidestepped the issue of assessing sincerity because 'no one has disputed the sincerity of [the] religious beliefs' of the families owning the plaintiff corporations. ${ }^{76}$ Consider, however, the potential role the conscientious objector cases and of fMRI technology might play in a future case where a similar claim is made whose sincerity is challenged.

The requirements of RFRA differ from those of the historical statutory exemptions from military service, but they both involve judicial assessments of the impact of a particular statute on an individual's sincerely held religious practice and beliefs. The statutory

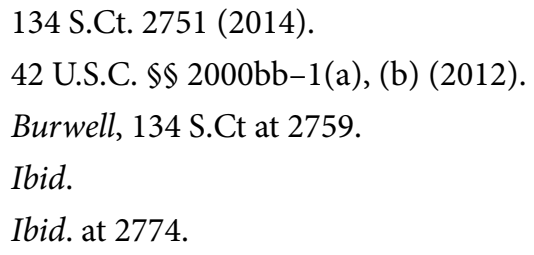


exemption for conscientious objectors was comparatively narrow and specific. As applied in Seeger, section 6(j) of the of the Universal Military Training and Service Act exempted from combatant training and service in the armed forces of the United States only those persons who by reason of their religious training and belief were conscientiously opposed to participation in war in any form. ${ }^{77}$ In contrast, RFRA, as invoked in Hobby Lobby prohibits the Federal Government from taking any action that substantially burdens the exercise of religion unless that action constitutes the least restrictive means of serving a compelling government interest. ${ }^{78}$ That is, where conscientious objection relates to a conflict between one specific law, (conscription), and one specific religious belief, (opposition to participating in a war), RFRA covers any law that substantially burdens any exercise of religion. If anything, the need to obtain an accurate assessment of sincerity would seem to be greater under the broad reach of RFRA.

It is important to parse just where and how sincerity of belief was discussed in Hobby Lobby. Justice Alito noted that the families owning the corporations held a 'sincere religious belief that life begins at conception. ${ }^{79}$ But that was not really where sincerity was most at issue. The crux of their claim was that the ACA contraceptive mandate forced upon them the 'choice of violating their sincerely held religious beliefs or making all of their employees lose their existing healthcare plans. ${ }^{80}$ Because of the relation of providing insurance coverage to third parties and their personal experience of violating their sincerely held religious beliefs was so indirect, the question really should have been one of the sincerity of the belief that complying with a general ACA mandate to provide insurance to employees, some of whom might someday make use of it to help pay for one particular form of contraception would substantially burden their religious practices. This then would make the case more akin to a conscientious objector case, insofar as the court would inquire as to whether the subject would sincerely experience participation in a particular state mandated activity (military service or insurance coverage of certain contraceptives) as a substantial burden on their religious practice. Given the incredible breadth of the statute, the only possible limitation on assessing whether a particular burden is substantial must necessarily take into account how it is experienced by the objecting party. Justice Alito, however, characterizes 'burden' in purely material terms, noting that ' $[\mathrm{b}]$ ecause the contraceptive mandate forces them to pay an enormous sum of money-as much as $\$ 475$ million per year in the case of Hobby Lobby-if they insist on providing insurance coverage in accordance with their religious beliefs, the mandate clearly imposes a substantial burden on those beliefs. ${ }^{81}$ The burden of forcing a conscientious

380 U.S. at $164-65$.

134 S.Ct. at 2759.

Ibid. at 2775 .

Ibid. at 2777.

Ibid. at 2779. 
objector to serve was not measured in terms of his exposure to the dangers of battle or any other material consequence of his induction. As the very term indicates, it involved a burden on matters of conscience. This is why sincerity was so critical. What the Court in Hobby Lobby failed to consider was whether or to what extent the ACA mandate imposed any similar sort of burden on the plaintiff corporations. That is, the Court looked at the material burdens imposed if Hobby Lobby refused to comply with the mandate but did not consider whether compliance itself would have imposed a substantial burden on the conscience (as it were) of the corporation; a burden, perhaps - but would that burden be substantial? To assess that, one would have to assess the sincerity of the claimants' assertions regarding how they would experience being indirectly complicit in the providing certain forms of contraception to their employees. ${ }^{82}$

Justice Alito noted that 'the plaintiffs ... assert that funding the specific contraceptive methods at issue violates their religious beliefs, and HHS does not question their sincerity. ${ }^{33}$ But there is a critical elision of two types of sincerity here: sincerity of the belief that using certain forms of contraception violates their religion, and sincerity of the belief that participating in the ACA mandate substantially burdens their ability to follow that belief. In this regard it is important to consider the attenuated connection between the religious beliefs of the plaintiffs and the ACA mandate. The plaintiffs held religious beliefs that life begins at conception. They further believed that the use of certain forms of contraception violated that belief. But the ACA did not compel them to use such contraception themselves, nor to provide them directly to their employees. Rather, it required them to provide health insurance that complied with ACA specifications. Those specifications included coverage of reproductive health services, which in turn, included the objected-to forms of contraception. In order to maintain a claim under RFRA, therefore, the plaintiffs should have been required to establish not only the sincerity of their belief that the use of such contraception violated their religious principles, but also the sincerity of their belief that complying with an ACA mandate to pay a third party to provide insurance for employees that covered such contraception constituted a similarly substantial burden on the free exercise of their religious beliefs. The issue, then is not simply the sincerity of the religious belief, but the sincerity of the assertion that the complained of practice substantially burdened the free exercise of that belief.

In addressing this issue, Justice Alito states, in these cases, the Hahns and Greens and their companies sincerely believe that providing the insurance coverage demanded by the HHS regulations lies on the forbidden side of the line, and it is not for us to say that their religious beliefs are mistaken or insub-

82 On the issue of complicity in Hobby Lobby, see NeJaime \& Siegel, Conscience Wars: ComplicityBased Conscience Claims in Religion and Politics, 124 Yale L.J. (forthcoming 2015).

83 Burwell, 134 S.Ct. at 2779. 
stantial. Instead, our 'narrow function ... in this context is to determine' whether the line drawn reflects 'an honest conviction', and there is no dispute that it does. ${ }^{84}$

But perhaps this is precisely where a dispute should lie; especially because, unlike the cases of Seeger or Welsh, the claims in Hobby Lobby implicated the interests of third parties beyond those seeking the protection of RFRA. Thus, there is a case for heightened skepticism of sincerity claims in cases such as Hobby Lobby because 1) the connection between the providing health care to third parties and burdening a religious practice based on a belief that life begins at conception is attenuate; and 2) there are third party interests in access to health care at stake.

Here is where fMRI tests of the future might have a role to play. In a Hobby Lobby-type situation an appropriately administered fMRI test need not get into questions of religious belief per se, but rather the sincerity of the experience of the burden placed on that belief by compliance with the objected-to statute. That is, fMRI might provide precisely the basis need to assess whether their conviction that complying with the ACA mandate was on the 'forbidden side of the line' was indeed 'honest'. Such an inquiry would not question the legitimacy of the underlying belief, nor the sincerity with which it was held. It would only address the sincerity of the assertion that compliance with a statute of general applicability would substantially burden that belief. It would therefore (theoretically) distinguish between assertions based on a person's (whether natural or corporate) sincere concern that compliance would burden their religious practice, versus assertions that sought primarily to extend and impose the dictates of that practice upon others. 